\title{
Challenged by Strong Communication Links
}

Citation for published version (APA):

Müller, R. J. (2002). Challenged by Strong Communication Links. Faculteit der Economische Wetenschappen en Bedrijfskunde. https://doi.org/10.26481/spe.20021004rm

Document status and date:

Published: 04/10/2002

DOI:

10.26481/spe.20021004rm

Document Version:

Publisher's PDF, also known as Version of record

\section{Please check the document version of this publication:}

- A submitted manuscript is the version of the article upon submission and before peer-review. There can be important differences between the submitted version and the official published version of record.

People interested in the research are advised to contact the author for the final version of the publication, or visit the DOI to the publisher's website.

- The final author version and the galley proof are versions of the publication after peer review.

- The final published version features the final layout of the paper including the volume, issue and page numbers.

Link to publication

\footnotetext{
General rights rights.

- You may freely distribute the URL identifying the publication in the public portal. please follow below link for the End User Agreement:

www.umlib.nl/taverne-license

Take down policy

If you believe that this document breaches copyright please contact us at:

repository@maastrichtuniversity.nl

providing details and we will investigate your claim.
}

Copyright and moral rights for the publications made accessible in the public portal are retained by the authors and/or other copyright owners and it is a condition of accessing publications that users recognise and abide by the legal requirements associated with these

- Users may download and print one copy of any publication from the public portal for the purpose of private study or research.

- You may not further distribute the material or use it for any profit-making activity or commercial gain

If the publication is distributed under the terms of Article $25 \mathrm{fa}$ of the Dutch Copyright Act, indicated by the "Taverne" license above, 


\section{Challenged by Strong}

Communication Links 


\section{Coloton}

Bashontwerp en realisatie: Unigraphic, Universiteit Maastricht

Foto omslag: http: /photo itsoft.ru

Alle pechten woorbehouden. Niets wit dere uitgave mag worden verweelvoudigd, opgeslagen in een geautomatiseerd gegevensbestand of openboar gemaakt, zander voarafgaande schriftelijke toestemming wan de auteur of witgever. 


\section{Challenged by Strong Communication Links}

Rede

Uitgesproken bij de aanvaarding van het ambt van Bijzonder hoogleraar in Quantitative Infonomics aan de Universiteit Maastricht op 4 oktober 2002

door

dr Rudolf Mülller 


\section{Challenged by Strong Communication Links}

Mijnheer de Rector Magnificus,

Zeer geachte dames en heren,

Bij iedere communicatie moet er een beslissing genomen worden welke taal men gebruikt. In het geval van deze rede is de keuze moeilijk omdat er geen tal is, welke alle toehoorders in deze ruimte tegelijk beheersen. Omidat onderwijs binnen de faculteit economie en bedrijfskunde nu bijna volledig in het engels gegeven wordt, krijgt de engelse taal ook voor deze rede de voorkeur.

The Internet connected in July 2002 more than 160 Million computers in the world.' More than 533 million people in the world have Intermet access ${ }^{\text {ii. }}$. Households with a high-bandwidth access are connected with a transmission rate of up to 5 million bits, zeroes and ones, per second. That means they can receive 300,000 ciphers or letters per second. Third generation mobile telephony is going to extend this connectivity further, providing the devices and the infrastructure to access all information sources on the World Wide Web from almost every point on the globe.

In this world, as soon as information is transformed into digital form, be the information a catalogue, yellow pages, a music $C D$, a video, or teaching materiall, and as soon as it is connected to the communication infrastructure there is essentially no physical limit to copy and to transport it instantaneously to any place. Whenever we feel that we have to communicate something we can do so. We post our opinion to a newsgroup, we extend our website, or we simply send an e-mail or an SMS. Information is in the airl iii

Customers and companies, organizations and individuals, students and teachers, they are all connected to strong communication links. Strong communication links constitute the virtual environment in which individuals and organizations operate. They change the way of 
working, our functions in teaching and research, our way of doing business and our private life. Nothing seems to limit this glorious development, and even after the burst of the Internet bubble being connected to the communication links, 24 hours a day, 7 days a week, is seen as a must for individuals and organizations.

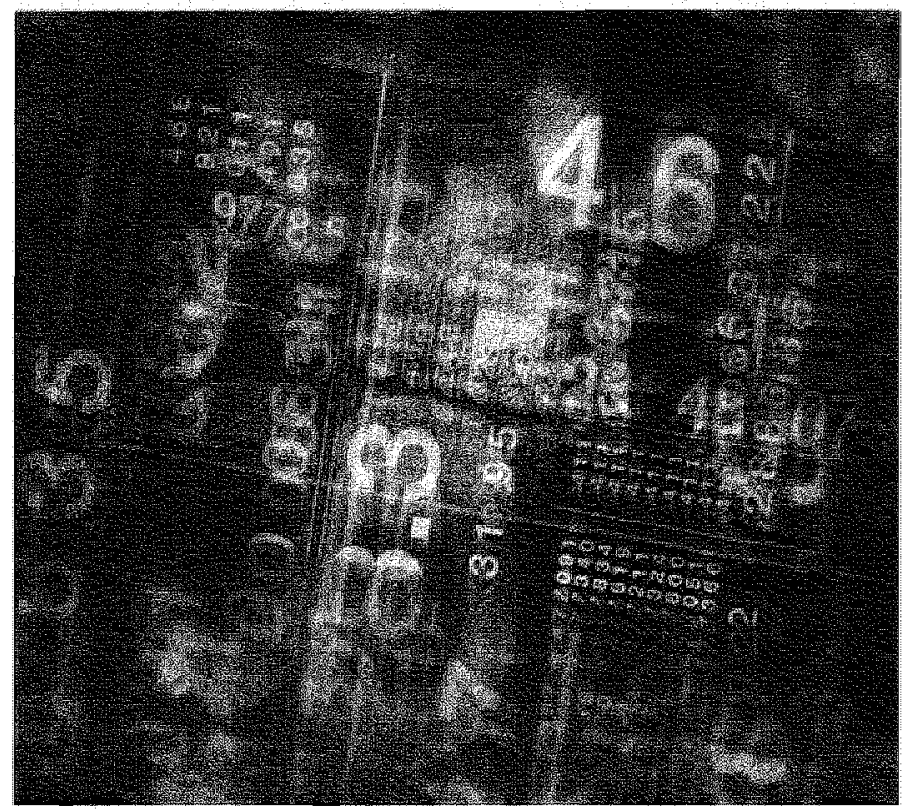

Figure 1: Information is in the air (source http://photo.itsoft.ru)

On the other hand the term information overload makes the round. Indeed, let us look alone at the physical limits of a human being: our eyes have a bandwidth of 10 million bits per second, our skin of 1 million bits, our ears and our smell 100,000 bits each, and our taste senses of 1,000 bits per second. If all our senses can be addressed at the same time, these numbers add to a total bandwidth of $11,121,000$ bits, of which only a small fraction goes into consciousness. Researchers estimate 40 bits from visual senses, 30 from acoustic senses, 5 through touch, and 1 bit taste and smell, respectively." If you compare these numbers with the 5 million bits of broadband bandwidth, supply must soon have reached demand, unless we store the information to consume it later. This gives a first indication that the transport capacities of the communication links thave reached a level that is much higher 
than the processing capacities of the nodes connected to the links, if the node is a human being. So let us replace in our calculation the human being by a computer.

A personal computer can currently perform about 1 billion instructions per second. While that sounds like a lot, it is not necessarily sufficient to deal with the enormous amount of data. Computer science tells us that for many decisions, which we might want to prepare by the help of a computer program, the computing part is the bottleneck, not the available data. Theoretical computer science provides evidence that this limitation cannot be overcome. Since the pioneering work of Cook in $1971^{v}$ thousands of problems have been proven to be computationally hard. Computationally hard means that likely every algorithm will in the worst case need an exponential number of operations in terms of the length of the input of the algorithm. To illustrate exponential growth, suppose that an algorithm needs one billion operations for an input of 1000 bits, in other words one second on a current PC. If the algorithm has exponential runming time, it will need for an input of double the size 11 days on the same PC. If we double the input again it will need more than 31000 years. This provides us with a second indication that the junctions in the virtual network the nodes connected to the strong communication links are very limited in terms of their processing capacities compared to the bandwidth through which they have access to information. This is in particular the case when the time needed for processing increases exponentially in the amount of information.

Thus, the scarcity of resources is located at the junctions of the information infrastructure, their capacities become the bottleneck in the virtual environment. We need to study these junctions and design carefully their interactions in order to benefit from the communication links. In the following I am calling the information processors on the junctions agents, a term that has been used in economics as well as in computer science. We should have in mind all kinds of agents: a comm. puter program, an organization, a company, or a human being.

One way to look at these agents, sitting on the junctions of the marvelous communication infrastructure, is to view them as mathematical mappings. Indeed, these agents are fed by sequences of o's and 
${ }^{\prime} \mathrm{s}$, and react to them by producing $\mathrm{O}^{\prime} \mathrm{s}$ and 1 's. Like mathematical functions they map numbers to numbers. Such mappings, call them algorithms, and their complexity have long been studied by computer scientists and operations researchers, in particular since the before mentioned work by Cook.

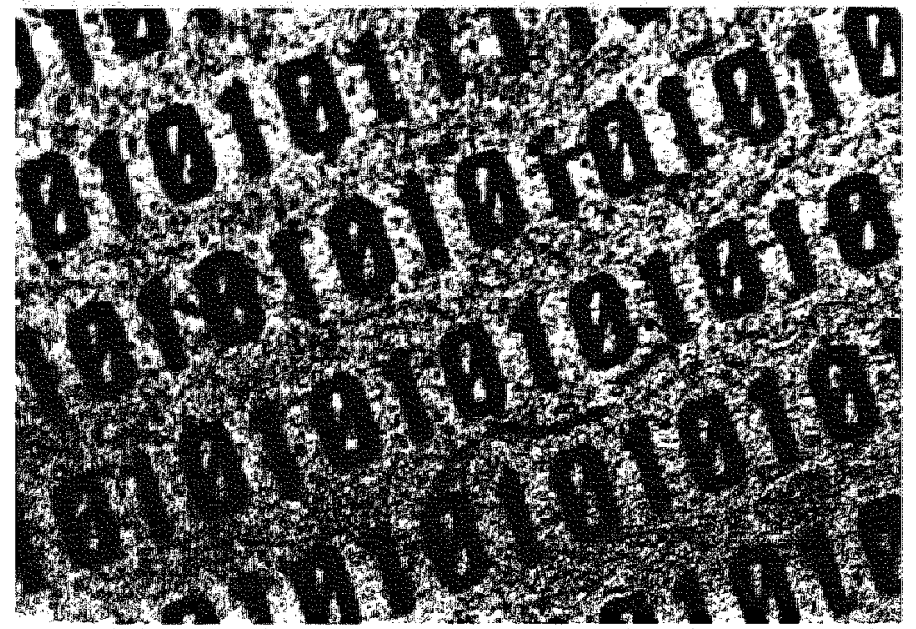

Figure 2: Agents get zeros and ones as input and produce zeros and ones (source: http://photo.itsoft.ru)

There is no doubt that there has been a tremendous progress in dleveloping mathematical theory and algorithmic techniques to speed up the computations, not to forget improvements in hardware. Larger and larger instances of decision problems can now be solved in reasonable time. Robert Bixby, the father of the CPLEX algorithm for linear programming, notes that there are problems that can be solved $65,000,000$ times faster than 15 years ago. "However "linear programming is in the sense of complexity theory not a hard problem. ".ii Let us therefore look at the traveling salesman problem, the problem where we search for a route for a sallesman through a set of cities such that no city, except from the starting point, is visited twice. Before you are starting to wonder why researchers try to solve traveling salesman problems in the time of e-commerce, I should mention that this problem has many other, still existing applications. In 1987 Grötschel and Holland where holding the world record by solving a traveling salesman problem with 666 cities. Almost 15 years later the current record 
is hold by Applegate, Bixby, Chvatal and Cook. They can solve an instance with 15112. The team reports: "The computation was carried out on a network of 110 processors located at Rice University and at Princeton University. The total computing used in the computation was 22.6 years scaled to a Compaq EV6 alpha processor running at 500 Mhz" . . $^{\text {.i }}$ Hence, for this member of the class of hard optimization problems 15 years of research were necessary to solve problems that have only 15 times more cities. If we compare this with the improvements in linear programming, it almost looks as if progress in software and hardware has increased the digital divide between easy and hard problems.

Is there then another way to circumvent the limits of computa. tional capacities of the agents? If many decision problems cannot be solved in reasonable time, can we simplify the decision for the agents? If agents cannot deal with large amounts of data, should we hide it partly? Are there ways to define the rules of coordination and interaction, such that agents can more easily benefit from their connectivity? Furthermore, some of the agents are still human beings, which come with skills that go beyond what we can capture with a mathematical model. How can these skills be incorporated? Good questions.

Let us therefore develop the madel further: a network of agents linked to each other by strong communication links, and characterized by limited computational capacity. Agents hold information and information can be exchanged instantly between them. New information is produced, and information is moved to other agents, changing the state of the system.

There are numerous examples of such systems that we might think of. Take as a first example an electronic stock market, with software and human trading agents. Human agents are connected to news agencies, documents with financial reports, results of economic research, and so forth. The market defines the rules of interaction: how to post buy and sell orders, how these orders lead to trade, and how trade changes prices. Price changes generate news, which influence again trade. The state of the system is characterized by the history of price changes, ownership of contracts, money endowment of the traders, and, if you want, information that is influenced by these changes. 


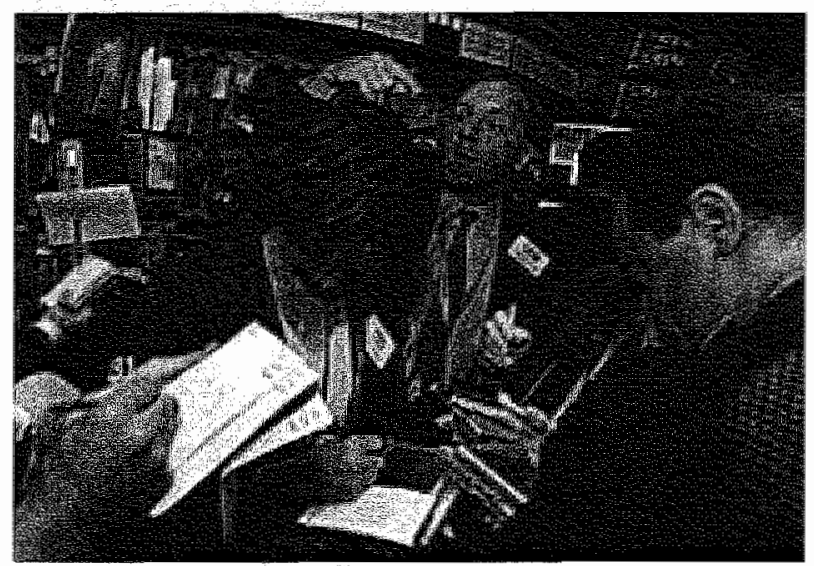

Figure 4: New York Stock Exchange (source www indystar,com)

Take as a second example the hundreds of auction sites on the Internet. Sellers post descriptions of objects that they want to sell, and buyers around the world submit bids to win the objects. State in terms of high bids changes permanently "partly driven through bidding agents. When winners are found ownership of objects and money endowment changes in the market.

As a third example we look at the information flow between customers and suppliers in supply chains. Firms agree on electronic data interchange by which data from their databases, like orders and production schedules, is sent automatically to the supplier in order to. reduce delays and inventory. Every event creates a change of the state of the system. Companies in the supply chain face suddenly a highly dynamic environment, forcing them to change their management of operations. New computational challenges emerge, because traditional offline planning approaches have to be replaced by online decision making. Furthermore, the design of the information exchange requires agreements how to share costs of implementation and benefits from improved efficiency. 


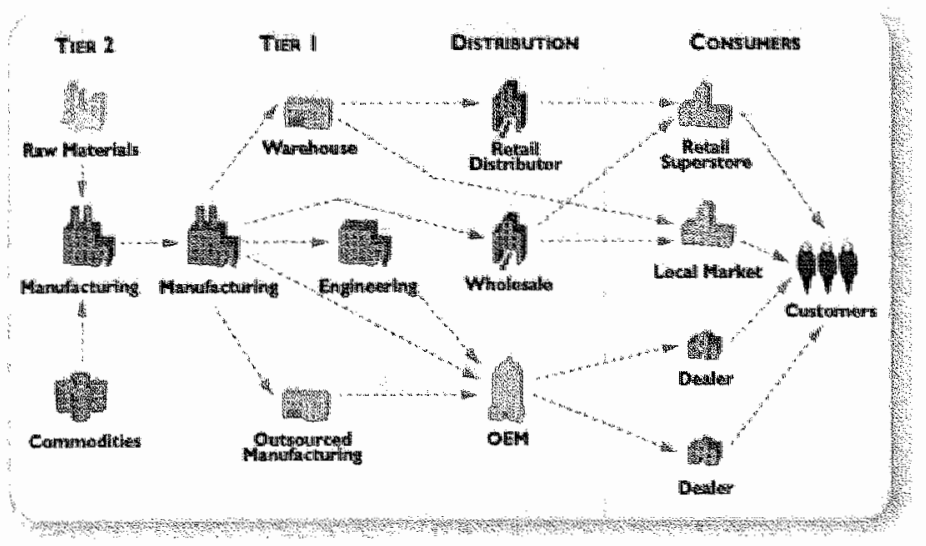

Figure 5: An automotive supply chain network (source www. qad com)

These examples of networks of agents connected by communication links have in common that, beyond a technical realization, they require a design of rules. The rules of the game determine the transitions and the outcome of the system. They determine the computam tional challenges that agents face, and they imply the strategic alternatives that agents have to achieve their own goals.

Of particular interest are rules that implement markets, and here again auctions. Auction research became during the last years a prominent topic of research in economics and computer science, mostly because of consumer auctions on the Internet, auctions for frequencies and auction-based coordination mechanisms in distributed computer systems. But auctions seem to provide as well an excellent case if we want to study the impact of coordination rules on computa. tional challenges of agents in a network. They are well understood from a mechanism design perspective, the field of economics that gets closest to this topic. Thus they provide a good starting point to extend established theory by algorithmic issues. I will illustrate this along two examples.

In the first example I will demonstrate how a continuous double auction is able to assemble distributed information. Those of you who participated in the two soccer markets that we organized at Infonomics together with colleagues from Humboldt University one and three 
years ago might recall the setup. In the second example, I illustrate the impact of rules on the complexity of decision making and information exchange in private-value, single item auctions.

Let me first get to example 1. It is an economic experiment that can be done in a computer laboratory or via the internet, going back to a paper by Plott and Sunder. ${ }^{*}$ The experiment tests to which extent a market is able to assemble distributed information owned by traders in the market. Assembling information is indeed a function that we hope financial markets are able to do. According to Hayek they should be able to transform the partial information that traders have into prices that reflect the strength of listed companies. ${ }^{x i}$ I have chosen the example to illustrate how powerful a system based on economic decisions of human agents can be, without a need for complex computational machinery or sophisticated rules.

In our experiment, we have got a box with 100 hundred bowls inside. Bowls are either white or black. Let us call the number of white bowls $x$, so there are $100-x$ black bowls. Every participant gets to see a small subset of the bowls and knows thus for her sample how many white and black bowls it has. Samples are arranged in a manner such that each individual bowl has been seen by exactly one agent. In other words, all agents together know how many bllack and white bowls there are. Now we design a market in which agents trade based on their information. The goal is that the market reveals the number of white and black bowls in terms of prices.

The market is a future market and trades two different contracts, White and Black. Their liquidation value will depend on the number of white and black bowls in the box in the following way. The value of a White contract will be $x$ Euracent, the value of a Black contract will be 100-x Eurocent.

The trading platform is set-up as follows. Each trader can buy unit portfolios from a virtual bank for a price of 100 Eurocent consisting of 1 White and 1 Black contract. The traders may un-bundle portfolios and trade individual contracts with other traders in a continuous double auction. Whenever a sell order matches the price of a buy order, trade is done. Otherwise orders are queued. The market closes after a certain 
amount of time, or when prices have stabilized. At market closing, the bank reveals the true number $x$ of white bowls and pays the liquidation value $x$ for every White and $100-x$ for every Black contract.

Balls seen by one of the

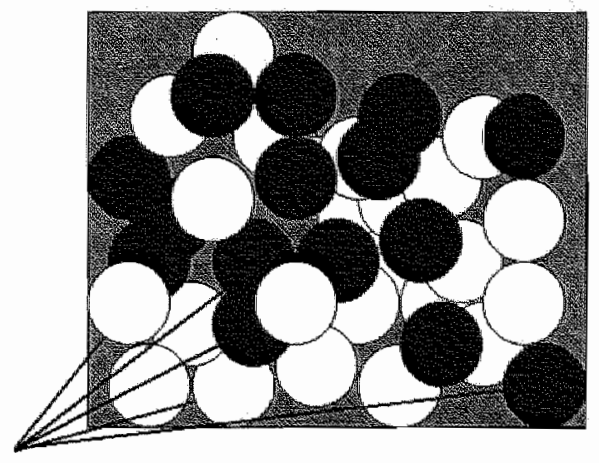

participantis:

2 white, 3 black

Figure 6: black and white bowis in a box, of which every participart gets to see a small sample.

Agents in this market have incentives to buy or sell due to their partial information: an agent who has seen many white bowls in her sample is likely to buy White contracts at a higher price than an agent who has seen a few. During the auction agents update their own estimates by observing price moves, which finally leads to a stabilization of the price. This experiment leads to final market prices for White and Black that are astonishingly close to $x$ and $100-x$, even with a small number of traders and a small number of transactions.

The same principle can be used in field experiments. In this case information owned by the traders are beliefs about future events, and we want to aggregate these belliefs into a prediction. I mentioned all. ready the soccer markets as an example. Of more interest are election markets. In these markets contracts represent political parties or candidates, and the liquidation value depends on the percentage that the party or candidate achieves in the election. Forsythe, Nelson, Neu. 
mann, and Wright tested prediction markets very successful in the US presidential elections in 1988 and achieved a better prediction than all other forecasts. ing. They all utilize the skills of human agents to translate own observations into a prediction of the election outcome, and translate this into trade: Surprisingly, this design is even robuist against irrational behavior, as long as a small set of traders behaves sufficiently rational.

Let us for a minute compare the information assembly in a prediction market with a traditional forecast based on polls. A traditional forecast selects a representative sample of voters and asks each voter: what are you going to vote? This information is fed to statistical methods. The agents participating in the poll reveal only little information, and a careful selection of the sample as well as complex statistical methods are required for a good prediction. Prediction markets can do without complex computations because they integrate the skills of the participants. Let me mention at this point that thanks to a Veni grant from the Dutch Science Foundation NWO to my Infonomics colleague Martin Strobel prediction markets are now being investigated in Maastricht, too.

Let me now come to my second example. It will introduce you to a new auction for selling a single item. I will show how the new set of rules can reduce the information that has to be exchanged to a minimum, while keeping the strategic decisions of agents simple. Because single item auctions do not sound very challenging, I will take a little more time to motivate the example.

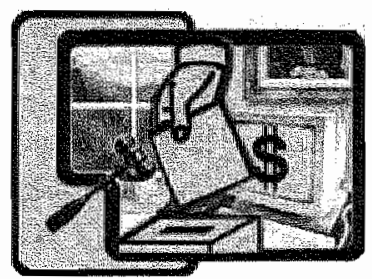

Figure 7: In 2000, vote-auction com entered the news because it offered US citizens to auction their votes via the site ${ }^{x i v}$ 
Following the success of consumer auctions in the early days of the World Wide Web, an increasing number of online business auctions are operational or under development. Large procurement orders can now be negotiated via online platforms, and participating industries report to achieve savings of up to 20 per cent. Not only commodities, like various office material, but also services, like leasing and maintenance contracts for copy machines, or cleaning services, are being auctioned via such platforms.

These new applications stimulated in the last five years a lot of research on auctions where bidders submit bids on bundles of abjects, also called auctions with package bidding, or combinatorial auctions." A package bid specifies for a combination of objects the maximum price that one is willing to pay if one gets all the objects together, or, in a procurement setting, the minimum price at which one is willing to sell these objects or services.

Take as an example the cleaning service setting, and suppose this university would use an auction to negotiate all contracts related to cleaning its buildings. One company who participates in this auction might observe that cleaning only the building in Tongersestrat 53 could be done at a lower price per square meter than cleaning Minderbroedersberg 4-6 as well. The reason might be that for a larger contract it would have to hire additional personnel. On the other side, a company might offer a better price, if it gets both the offer for windows and the floors. In an auction with package bidding one would divide the total cleaning contract into many small parts. Flexible package bids would allow companies to compete for self-chosen combinations of these parts. They internalize complementarities or substitutes that suppliers observe. Bundle bids make economically sense whenever auction wants to trade several objects at the same time, and objects are related this way. For example, the US Federal Communications. commission has decided to allow package bidding in auction 31 scheduled for lanuary 2003. Package bids are however very challeng. ing when it comes to computation and communication.

In terms of computation they raise the isswe of winner determination: Given a large set of package bids for the cleaning services in our university, one would have to compute a set of winning bids that cov- 
ers all individual tasks at a minimum price. This is one of the many hard optimization problems that I mentioned earlier. Combinatorial auctions require thus significant computational effort. There is also a large communication effort involved. We can easily imagine, that for a single company, many different combinations might be attractive. Hence the company needs to make a large number of bids to present its preferences. Indeed, the number of bids would in the extreme case be exponential in the number of tasks. That makes the bidding itself almost intractable. Noam and Segal have shown that even in special settings of user preferences, exponential many bids are necessary in order to guarantee economic efficiency.

These negative results do not imply that winner determination and communication complexity in combinatorial auctions is always hopeless from a complexity point of view. If the number of objects is small like in frequency auctions, optimization problems can still be solved and the number of bids becomes manageable. But also special structure may help. For example, if we would auction pieces of real estate along a seashore, and restrict bids to neighbored lots, then the number of feasible bid is quadratic in the number of lots, and winner determination can be done efficiently. ${ }^{\text {xili }}$ However these arguments apply only with respect to a single round in such auctions. While procurement auctions are classically done in a single round from which the winner is determined, many applications ask for multiple rounds. Multiple rounds let bidders increase their bids and thereby react to other bids. In a combinatoriall auction bidders may chose to bid on different bundles in different rounds. The mentioned package bidding auction for frequencies in the US is of that flavor. If we want to allow several rounds in an auction design, the question arises how many rounds we need?

This leads me to my second example, in which I show you how we can reduce the number of rounds in an auction. At the same time, this example will show, how the information which bidders have to reveal during the auction can be minimized. The example will be about the straightforward case where an auctioneer sells a single object, and where every bidder has a private valuation of this object. Figure 8 shows a painting to be auctioned and valuations of 4 bidders that I am going to use in my example. 
The obvious choice of a multi-round auction would be in this case the English auction. The English auction starts with some reservation price, and bidders may outbid a high bid of other bidders. Bidders can play an obvious strategy, namely increase the highest bid as long as it is lower than their own valuation. However, a large number of bids might be required until the auction finishes. For example if bid increments may be arbitrary small, the auction might never end, unless the auctioneer stops it.
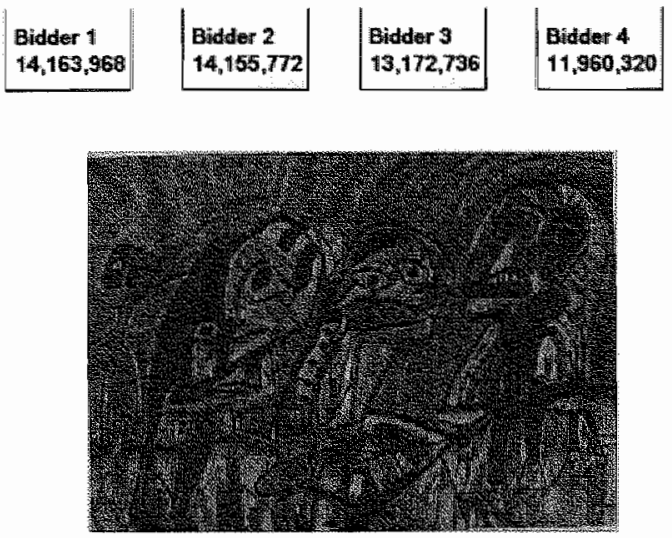

Figure 8: Valuation of 4 bidders competing for a painting

Therefore we need minimal bid increments. If the auction proceeds in steps of 1, however, the speed is still very low. In the example there are more than 14 million increments necessary until bidder 1 becomes the winner. From a theoretical perspective the number of rounds is exponential in the number of digits needed to represent the input. Large bid increments have unfortunately a negative impact on the economic efficiency. For example, with a constant bid increment of 10,000 , bidder 2 might win against bidder 1 , although bidder 1 values the object more.

If the rules of the English auction require a too large number of rounds, is there then an alternative set of rules that reduces the number of rounds? Well, we could fall back on the sealed bid auction: every bidder makes exactly one bid, and the bidder with the highest bid wins 
and pays the price equal to her bid. However, in this case making a good bid is not easy. Whenever one wins, one might have won with a slightly lower bid, too, paying less. Information about what your competitors are going to bid becomes wery valuable, as can be followed in the Dutch news these days.

However, the difficulty of computing a good bid can be overcome by a change in the design. William Vickrey published in 1961 a paper with a single-round sealed bid auction that makes bidding easy. rey's suggestion: you let every bidder make exactly one sealed bid, you allocate the object to the bidder with the highest bid, but you let him only pay a price that is equal to the second highest bid. Under these rules, whatever your competitors in the auction bid, you do best if you bid your own valuation. Indeed, since your bid does not influence the price that you pay, you should always bid at least your valuation, to increase your chances to win. You should however not bid more. If bidding more makes you the winner, while bidding the valuation would have made you a looser, you will pay more than your valuation. Bidding the truth is thus the best response against any strategies played by the competitors. In game theoretic terms we say that truthtelling is then a weakly dominant strategy.

Despite the advantage of the Vickrey auction that bidders do not have to reason about bidding, the auction did not become very popular. It misses the update possibility, and more importantly it requires that all bidders tell the auctioneer their complete valuation. In other words, it reveals more information about bidders private values than the English auction. After all, the only information that the auctioneer would have to know is the second highest valuation and the identity of the bidder with the highest valuation. In a recent paper, Elena Grigorieva, Jean-Jacques Herings, Dries Vermeulen and I suggest an auction that inherits the strategic easiness from the Vickrey auction, but reveals in some sense only the minimum imformation required. ${ }^{x x}$ It is a multi-round auction, but nevertheless very fast. We gave it the name bisection auction, because it uses the bisection method from Operations Research. Here comes how this auction works.

Let us assume that we know an upper bound on the valuations of the bidders, say 16777215 , which is equal to $2^{24}-1$, and that our reser- 
vation value is $2^{23}$. The bisection auction is a game by which we search for the bidder who has the highest valuation, and for the exact value of the second highest valuation.

For this second highest valuation, two properties hold: there are two bidders, who have a valuation that is at least equal to this value, and there is at most one bidder who has a waluation higher than this value. We start our search for a value with these properties in the interval spanned by the reservation price and the upper bound, in our case the interval from $2^{23}$ to $2^{24}-1$. We ask the bidders the following question: 15 your valuation greater than or equal to the middle of the current interval, in our case $2^{23}+2^{22}$. If two or more bidders answer yes, then we know that we have to continue our search in the part right to the middle. If no bidder says yes, we know that we have to continue our search in the left part of the interval. If exactly one says yes, then we know that we have to continue in the left part, too, and, as a side effect, that the bidder who said yes has the highest valuation. In the next round we ask the same question for the middle of the interval to which the answers in the previous round have led us. The figure shows the intervals we will reach in the first 5 rounds, given the valluations from Figure 8 , and given that bidders tell the truth.

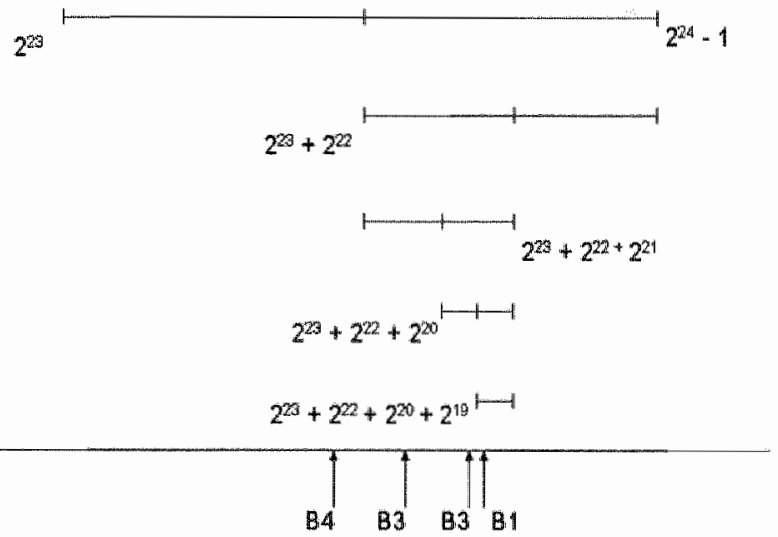

Figure 9: decreasing search intervals in the bisection auction 
Note, that the size of the interval decreases that fast that we are done after a number of rounds logarithmic in the length of the initial interval. In our example we know the winner even after 4 rounds. To illustrate why we cannot hope to do better, we write the bidders valua tions in binary encoding, and get the following leading 9 digits for our 4 competitors:

\begin{tabular}{|l|l|}
\hline Bidder 1 & 110110000 \\
\hline Bidder 2 & 110101111 \\
\hline Bidder 3 & 110010010 \\
\hline Bidder 4 & 101101101 \\
\hline
\end{tabular}

The questions asked by the auctioneer check systematically the leading digits of the valuations, starting from digit 2 because of the reservation price. We see for example that the fact that bidder 4 says "no" is reflected by a 0 as a second digit of her valuation. On the other hand, it is crucial to check this second digit, because it is the only one that identifies bidder 4 as being not competitive. Once bidder 4 is out, we will not have to ask bidder 4 another question. The next interval in the bisection will keep us with the bidders with a 1 in position 2, and our question will check for the third digit. This way we extract the minimal amount of information that is needed in a second-price single item auction.

A drawback that this method might still have is that bidders are not honest. They might play strategically rather than replying the truth to our questions. Interestingly, this can be excluded as well. If we let bidders make sealed bids in every round, and if we do not announce the content of the bids, then we can prove that answering our questions correctly is a weakly dominant strategy: whatever other bidders play, the best strategy is to tell in every round the truth. This property together with the communication efficiency makes the bisection auction in some sense the best auction one can hope for in the single item, private value case. The next step will be to extend this efficient search for the appropriate information to multi-item auctions, a project that is supported as well by NWO. 
My first example has shown that a combination of a straightforward double auction with human agents as participants can be used to assemble distributed information. My second example has shown that we are able to build auctions for the single-item private vallue case that extract exactly the information that is needed. The combination of mechanism design, game theory and computer science is still at the beginning of its development. But I am convinced that this combination, embedded in experimental studies that incorporate human skills can provide a fruitful toolset to design efficient systems of agents connected to strong communication links. As a member of the faculty of economics and business administration of the Universiteit Maastricht 1 am lucky to have an environment where all the expertise that is required to develop this toolset is represented through excellent researchers from their fields. But not only the scientific quality of my working enviromment makes it so distinct. The heartily way of cooperation and the responsibility that people take for each other makes working in this environment a pleasure.

I would like to thank the department of Quantitative Economics and its head Hans Peters for the trust that you have in me, and for the support that you give to my work. In particular, I would like to thank my section Operations Research with its head Antoon Kolen, who made me a little more than 4 years ago a job offer in Maastricht. This brought me back to Operations Research, after a 4,5 year trip to information systems at Humboldt Universität zu Berlin. At that time I had almost lost my links to my former field of expertise, and it was therefore a surprising turn in my academic work. What I didn't expect when I started here was how much I should profit from my work in information systems. I would like to thank Oliver Günther for the fruitful cooperation during the years at Humboldt. It were in particular these years in my academic past that taught me to work in an interdisciplinary environment, and to benefit from the cooperation with colleagues from business administration and economics, in order to see beyond the classical models from Operations Research.

The foundation for my work in Information Systems was laid already a couplle of years earlier. That leads me to the point where I would like to thank my academic father Rolf Möhring. He asked me in 1987 to become a research assistant in his working group on applied 
discrete mathematics that he was founding at Technische Universitat Berlin. Without any knowledge in programming, except programming in Fortran with punch-cards in 1982 , a challenging time began, in which we thought about algorithms for improved computer chip layout ${ }^{x \times 1}$, taught students to program in Pascal and $\mathrm{C}++$, and started to build software systems for optimization. From that time on combinatorial optimization and software systems were competing for my time. In 1990 I wisited for the first time the FAW in UIm, whose director FranzJosef Radermacher worked with us on the vision of advanced decision support systems based on Eigenmodels.xii Many colleagues with whom I worked later in the MMM $^{\text {xxili }}$ and the DecisionNet ${ }^{\text {xxiv }}$ project I met there for the first time. I would like to thank today Rolf Möhring, for many years of support an so many different issues.

Looking back to the 4 years in Maastricht, communication was not only the guiding principle in my research. Maybe because it was so hard to judge what my research is about, many other communication links emerged very soon. The most influential link became Luc soete. Luc, as a member of your Infonomics team I got once again the opportunity to develop ideas in an interdisciplinary environment. Although I am standing here as the first professor of Infonomics in the world, the circumstances did not yet develop toward the fertile ground that we have dreamed of for Infonomics two years ago. We are still in charge to prove where Infonomics research and Infonomics education makes a difference to established disciplines. As in every new fiell this will take some time, but I am sure that we will be successful. I would like to take the opportunity to encourage everybody in the room to support the Infonomics team in this challenge.

A year ago I was asked to become a member of the faculty board, leading to membership in 4 other platforms and boards in the faculty and the university. That was the time when $\|$ definitely got challenged by strong communication links. Now my table is covered with reading material on ICT, e-learning and internationalization, not to mention the generall issues of the faculty board that have to be studied. But it is a great experience to be a member of this board, and to be involved in important strategic decisions for the faculty and the university, like the e-learning project. 
Alles hat natürlich einen Anfang. Und der liegt so weït zurück wie der zitierte Artikel von Vickrey. Liebe Mama, ich freue mich ganz besonders, dass ich heute mit dir diesen Tag feiern darf. Uber viele Jahre haben Du und Papa mich mit Rat und Tat begleitet. Es gab viele wichtige Weichenstellungen, bei denen du Heike, Otmar und mir eine Richtung gegeben hast, und es gab viele schwierige Phasen, in denen deine Unterstützung unsagbar hilfreich war. Heike, Otmar, und Anja, auch Euch gilt mein besonderer Dank für die besondere familiäre Atmosphäre, die uns verbindet. Ich möchte mich auch bei all den lieben Freunden bedanken, die teilweise auch heute hier sein können. Es ist schön, dass unsere communication links so stabil sind. Ich danke Euch dafür.

And then, there is a very special communication link, the closest overall that I have. Dear Sonja, I would like to thank you for the wonderful time we have together and the patience you have these days with my full agenda of duties and ideas. I wish you the strength to convince me more often to choose for less connectivity and more time instead for us and our friends.

lk heb gezegd.

i see http://wWw.isc.org/ds/WWW-200207/index.html

if see http://www.nua.ie/surveys/

iii a frequently used phrase, see www.google.com, for example: Donie

A. Nelson, How important is it to live in Los Angeles?,

http://wmwhollywoodnet.com/Nelson/columns/losangeles.html

iv Tor Norretranders (1998), The User Illusion, Pinguin Books.

${ }^{*}$ Stephen Cook (1971). The complexity of theorem proving procedures.

In Proceedings of the Third Annual ACM Symposium on Theory of Computing, pages 151-158.

vi See http://www.ilog.com/products/optimization/.

times winter2001/tech historical.cfm. 
wil L. Khachian (1979). A Polynomial Algorithm inLinear Programming. Soviet Mathematics Doklady 20, pages 191-194.

witi Solving TSPs. http:/Www.math.princeton.edu/tsp/index.html.

ix Nisan, N., and Ronen, A. (1999), Algorithmic Mechanism Design, Proceedings of the ACM Symposium of Theory on Computing, extended version at http: //www.cs.huji.acill/ noam * Plott C. R. and Sunder. S. (1988), Rational Expectations and the aggregation of diverse information of divers information in laboratory securities markets", Econometrica 56, pages 1085-1118.

${ }^{x i}$ Hayek, F. A. von (1945), The Use of Knowledge in Society, The American Economic Review, 35, pages 519-530.

xil Forsythe, R., Nelson F., Neumann, G., Wright, J. (1992), "Anatomy of an Experimental Political Stock Market" ,American Economic Review 82, pages $1142-1161$.

xill Forsythe, R., Rietz, T. A., Ross, T. W. (1999), Wishes expectations and actions: a survey on price formation in election stock markets. Journal of Economic Behavior \& Organization, 39, pages 83-110.

${ }^{\text {xiv }} \mathrm{CNN}$, Website says vote auction was just a 'game', November 10 , 2000 , www.cnn.com/2000/TECH/computing/11/10/vote auction.idg/. *V Sven de Vries and Rakesh Vohra, Combinatorial Auctions - a Survey. Accepted for publication in Informs Journal on Computing. *ii Federal Communications Commission, Auctions of Licences in the 747-762 and 772-792 MhZ Bands, Washington, DC, March 19, 2002. http://wireless.fcc.gov/auctions/31/releases/da020659.pdf 
xvil Noam Nisan and llya Segal (2002), The Communication Complexity of Efficient Allocation Problems. Working paper. Hebrew University, Jerusalem, Israel, March 2002.

xviii Müller, R. and Van Hoesel, C.P.M. (2001), Optimization in Electronic Markets: Examples in Combinatorial Auctions. Netnomics, 3, pages 2334. xix William Vickrey (1961), Counterspeculation, Auctions, and Competitive Sealed Tenders, Journal of Finance, 16/1, pages 8-37. ${ }^{x x}$ Griegorieva, E., Herings, P. J.-Jx, Müller, R., Vermeulen, D. (2002), The private value single item bisection auction. Working Paper, Universiteit Maastricht.

${ }^{x \times i}$ Müller, R., and Wagner, D. (1991), Alpha Vertex Separator is NP. complete even for 3"Regular Graphs, Computing 46, pages 343-353. xxili Möhring, R.H., Müller, R., and Radermacher F.-J. (1995), Advanced DSS for Scheduling: Software Engineering Aspects and the Role of Eigenmodels, in Annals of Operations Research, 55, pages 453-469. xxiii Günther, O., Müller, R., Bhargava, H., Krishnan, R., Schmidt, P. (1997), MMM - a WWW Based Method Management Systems for Using Software Madules Remotely, Internet Computing, 1, 1997, pages 59-68. xxiv Bhargava, H. Krishnan, R., Müller, R. (1997), Decision Support on Demand, Emerging Electronic Markets for Decision Technologies, Decision Support Systems, 19, pages 193-214. 